Contemporary Journal of African Studies 2019; 6 (1): 96-113

https://dx.doi.org/10.4314/contjas.v6i1.6

ISSN 2343-6530

(C) 2019 The Author(s)

Open Access article distributed under the terms of the

Creative Commons License [CC BY-NC-ND 4.0]

http://creativecommons.org/licenses/by-nc-nd/4.0

\title{
Teaching Social Studies from multicultural perspective: a practical approach to re-fashion African Studies for transformation
}

\section{E. T. Salako and O. A. Ojebiyi}

Dr.Ekima Tina Salako,Lecturer, NationalTeachers'Institute,salakoekima@yahoo.com

Dr. Olufemi Adesola Ojebiyi, Associate Professor, Obafemi Awolowo University, Nigeria, olufemiadesola@yahoo.com

\begin{abstract}
Currently, global education and global citizenship for social transformation addresses the issues of cordial and harmonious existence of our time. Africa is a multilingual and multicultural continent with about 3.000 ethnic groups and 2000 languages spoken; therefore, introduction of multicultural approach in teaching will ensure effective socialization and transformative education in Africa. The roots to challenge bias, prejudice and creating classroom environment that reflects the learner's culture for national unity lies in multicultural education. Multicultural education is a system of instruction which attempts to foster cultural pluralism and acknowledges the difference between race and culture in order to promote societal change and orderliness. This work examined a multicultural educational strategy which could be used in helping students from diverse racial, cultural, ethnic and language groups to experience academic success. Multicultural Concepts Knowledge Test ( $\mathrm{r}=0.82$ ), Multicultural Concept Attitude Scale ( $\mathrm{r}=0.86)$ were administered on 251 junior secondary school students from five secondary schools in the south-west region of Nigeria using the simple random technique. Two null hypotheses were formulated and tested at 0.05 level of significance. Data were analyzed using descriptive statistics, analysis of covariance. Treatment had significant main effect on students' posttest knowledge scores in multicultural concepts $\left(\mathrm{F}_{(2,340)}=5.835 ; \mathrm{p}<.05\right)$. and attitude to multicultural concepts $\left(\mathrm{F}_{(2,340)}=34.055\right.$; $\mathrm{P}<.05)$. The MCA shows that the cooperative learning group had higher adjusted posttest knowledge score $(\mathrm{x}=10.14$; Dev. $=.83$ ) In summary, findings of this study revealed that the cooperative multicultural learning strategy is effective for teaching multicultural classrooms. Therefore, this calls for improved approaches towards teaching by educators in order to bring us closer to the goal of multicultural education
\end{abstract}

Keywords: social studies, multicultural education, transformation, socialization, diversity 


\title{
Teaching Social Studies from Multicultural Perspective: A Practical Approach to Re-fashion African Studies for Transformation
}

\author{
E. T. Salako and O. A. Ojebiyi
}

\begin{abstract}
Currently, global education and global citizenship for social transformation addresses the issues of cordial and harmonious existence of our time. Africa is a multilingual and multicultural continent with about 3.000 ethnic groups and 2000 languages spoken; therefore, introduction of multicultural approach in teaching will ensure effective socialization and transformative education in Africa. The roots to challenge bias, prejudice and creating classroom environment that reflects the learner's culture for national unity lies in multicultural education. Multicultural education is a system of instruction which attempts to foster cultural pluralism and acknowledges the difference between race and culture in order to promote societal change and orderliness. This work examined a multicultural educational strategy which could be used in helping students from diverse racial, cultural, ethnic and language groups to experience academic success. Multicultural Concepts Knowledge Test ( $\mathrm{r}=0.82)$, Multicultural Concept Attitude Scale $(r=0.86)$ were administered on 251 junior secondary school students from five secondary schools in the south-west region of Nigeria using the simple random technique. Two null hypotheses were formulated and tested at 0.05 level of significance. Data were analyzed using descriptive statistics, analysis of covariance. Treatment had significant main effect on students' posttest knowledge scores in multicultural concepts $\left(\mathrm{F}_{(2340)}=5.835 ; \mathrm{p}<.05\right)$. and attitude to multicultural concepts $\left(\mathrm{F}_{(2,340)}=34.055 ; \mathrm{P}<.05\right)$. The MCA shows that the cooperative learning group had higher adjusted posttest knowledge score $(\mathrm{x}=10.14$; Dev. $=.83)$ In summary, findings of this study revealed that the cooperative multicultural learning strategy is effective for teaching multicultural classrooms. Therefore, this calls for improved approaches towards teaching by educators in order to bring us closer to the goal of multicultural education
\end{abstract}

Keywords: Social Studies, Multicultural Education, Transformation, Socialization,

Diversity

\section{Résumé}

Actuellement, l'éducation et la citoyenneté mondiales pour une transformation sociale abordent les questions de l'existence cordiale et harmonieuse de notre époque. L'Afrique est un continent multilingue et multiculturel avec environ 3000 groupes ethniques et 2000 langues parlées. Par conséquent, l'introduction d'une approche multiculturelle dans l'enseignement assurera une socialisation efficace et une éducation transformatrice en Afrique. L'éducation multiculturelle offre l'outil

https://dx.doi.org/10.4314/contjas.v6i1.6

Dr. Ekima Tina Salako (Email addresses: salakoekima@yahoo.com) lectures at the National Teachers' Institute, Nigeria. Dr. Olufemi Adesola Ojebiyi (Email addresses: olufemiadesola@yahoo.com) is an Associate Professor at the Obafemi Awolowo University, Nigeria. Their research interests include multicultural education, social studies education, security education, family life education and mentorship education and they have consistently written on multicultural issues. Some of their published articles are: Group Dynamic Concepts in Social Studies as a Correlate of Moral Values and National Unity, Teaching Social Studies from a Multicultural Perspective: A Practical Approach to Re-Fashion African Studies for Transformation, Multicultural Mentorship Education: A Critical Tool for National Unity and Integration. 
pour la lutte contre les partis pris, les préjugés et la création d'un environnement de classe qui reflète la culture de l'apprenant et, ce, pour renforcer l'unité nationale. L'éducation multiculturelle est un système d'enseignement qui cherche à promouvoir le pluralisme culturel et qui reconnait la différence entre la race et la culture afin de promouvoir le changement de la société et l'ordre. Ce travail a examiné une stratégie éducative multiculturelle qui pourrait être utilisée pour aider les élèves issus de divers groupes raciaux, culturels, ethniques et linguistiques à obtenir le succès scolaire. Les Multicultural Concepts Konwledge Tests [test sur la connaissance de concepts multiculturels] $(\mathrm{r}=0,82)$ et la Multicultural Concept Attitude Scale [la grille d'évaluation de comportement envers les concepts multiculturels] $(\mathrm{r}=0,86)$ ont été administrés à 251 élèves du premier cycle de l'enseignement secondaire dans cinq écoles secondaires de la région sud-ouest du Nigéria, à l'aide de la technique d'échantillonnage aléatoire simple. Deux hypothèses nulles ont été formulées et testées à un degré de signification de 0,05 . Les données ont été analysées à l'aide de la statistique descriptive et d'une analyse de covariance. Le traitement a eu un effet principal significatif sur les notes obtenues sanctionnant les connaissances des étudiants au posttest en ce qui concerne les concepts multiculturels $\left(\mathrm{F}_{(2,340)}=5,835 ; \mathrm{p}\right.$ $<0,05$ ) et en ce qui concerne le comportement envers les concepts multiculturels ( $\mathrm{F}$ $(2,340)=34,055 ; \mathrm{P}<0,05)$. L'ACM montre que le groupe d'apprentissage coopératif a obtenu une meilleure note au posttest $(\mathrm{x}=10,14$; Dév. $=0,83)$. En bref, les conclusions de cette étude ont révélé que la stratégie d'apprentissage coopératif multiculturel est efficace pour l'enseignement de classes multiculturelles. Ainsi, les éducateurs doivent adopter de meilleures approches de l'enseignement afin de nous rapprocher de l'objectif de l'éducation multiculturelle.

Mots-clés: études sociales, éducation multiculturelle, transformation, socialisation,

diversité

\section{Introduction}

Multicultural education is a set of strategies and materials in education that were developed to assist teachers to promote democracy while responding to the many issues created by the rapidly changing demographics of their students (Banks, 2008). Multicultural education maintains that all students should have equal opportunities to learn regardless of the racial, ethnic socialclass or gender group to which they belong. It is imperative to note that as the world continues to exhibit great diversity, the need for understanding and accepting the differences among all people has never been more important. Thus, the challenge for educators is to present an effective multicultural education foundation by means of which all students can learn to accept others.

The historical roots of multicultural education lie in the civil rights movement of various historically oppressed groups. According to Davidman (1997), the history of multicultural education can be traced back to the social action of African Americans and other people of colour who challenged discriminatory practices in public institutions during the civil rights struggles of the 1960s. Activists, community leaders and parents called for curricular 
reform in educational institutions instead of re-examination of hiring practices. Also, in the late 1960s and early 1970s, the women's rights movement joined this push for education reform. Women's right group challenged inequalities in employment and educational opportunities as well as income, identifying multicultural education as a progressive approach for social transformation.

In the face of these struggles, James Banks, one of the pioneers of multicultural education examined schools as social systems from multicultural context. He opined that in order to maintain a multicultural school environment, all aspects of the school had to be examined and transformed, including policies, teachers, attitudes, instructional materials, assessment methods, counseling and teaching styles. It is therefore very certain that multicultural education advocates the belief that students and their life histories and experiences should be placed at the center of effective teaching and meaningful learning process. Multiculturalism recognizes the existence of diverse cultures in one country. The world is a global village and this awareness forces us to respect and understand other people's cultures. Such an understanding and respect for other cultures are not inborn attitudes; they are learned at school through multicultural education.

Globally, dramatic changes in information technology are positively affecting the awareness of students in classrooms and changing their aspirations too. With internet connectivity and computers, with or without the teachers, students are likely to get access to information about many countries. Perhaps because of this exposure, students want to be global citizens with skills that can make them globally competitive. This is a trend that points in a very different direction from the localism of a multicultural education with an emphasis on a language and a teaching practice rooted in the students' own culture. New media makes available a wealth of literature and information on different cultures. It can help open up closed communities. On the other hand, it takes not only access but also literacy to draw value from the new media, literacy either in terms of spoken language, written languages or the ability to understand and use symbols, images and other forms of content. In all, multicultural education is needed for global unity and peaceful co-existence.

\section{Multiculturalism in Africa}

The total population of Africa is estimated at 1.1 billion representing approximately $15 \%$ of the world's population (PRB, 2016).The cultural diversity of Africa has long been recognized. These differences are gender, age, language, culture, race, sexual identity and income level to mention a few. Audrey (1995) provided a detailed account of linguistics, religious and cultural differentiation of communities in East Africa in a book entitled The Multicultural State of East Africa. One of the contested concepts in 
multiculturalism is assimilation; an example from Ethiopia provides a unique insight into this policy. Assimilation implies the eradication of difference in favour of the dominant culture thereby promoting cultural superiority which multiculturalism seeks to oppose.

Before 1994 the Republic of South Africa had separate education systems for the various cultural/ethnic groups. After the South African election in 1994, the education system changed and public schools in South Africa opened their doors to all learners (Venter, Franzsen \& Van Heerden, 2000). Opening schools to all cultures marked the official start of multicultural education in public schools in South Africa. In the West African sub region, countries like Nigeria, Ghana, Guinea, Niger, Togo, Sierra Leone, Senegal, Gambia and Burkina Faso to mention a few, are multilingual, multiethnic and multi-religious nations. The countries have been concerned with maintaining unified polity. People of different ethnic, tribal and national origins live in these countries. Additionally, multinational companies such as MTN, Aitel, Unilver, BP, Toyota, Pfizer, ExxonMobil. GlaxoSmithKline's, and others employ people from different backgrounds who work and live in these countries. Hence, there is intense need for Multicultural Education.

However, multiculturalism in North Africa and in the Arab world at large has reached a significant level in terms of scale and importance. In the rest of the world there has been a trend-albeit a contested one towards a greater recognition of minority rights. The Arab world particularly North Africa, seems to be an exception to this trend as Arab states continue to promote highly unitary and homogenizing ideas of neigbourhood and state unity (Moha, 2014). This negative attitude towards diversity in a $21^{\text {st }}$ century global world is due to inadequate knowledge of Multicultural Education.

People in heterogeneous societies such as found Africa are characterized by groups, class, beliefs, attitudes, values, interests and intentions. These diversities have been positively harnessed for greatness by other nations of the world however, the case is quite different in some parts of Africa due to inadequate knowledge of Multicultural Education. Therefore, teaching from a Multicultural perspective will encourage appreciation and understanding of other cultures as well as one's own. Teaching with multicultural strategies promotes children sense of uniqueness of his own culture as a positive characteristic and enables children to accept the uniqueness of the culture of others; this is important because classrooms today are becoming increasingly diverse. Teachers must seriously consider issues such as race and ethnicity. As displayed in the figure below, the learner is at the center of learning experiences and all other factors surrounds him. 


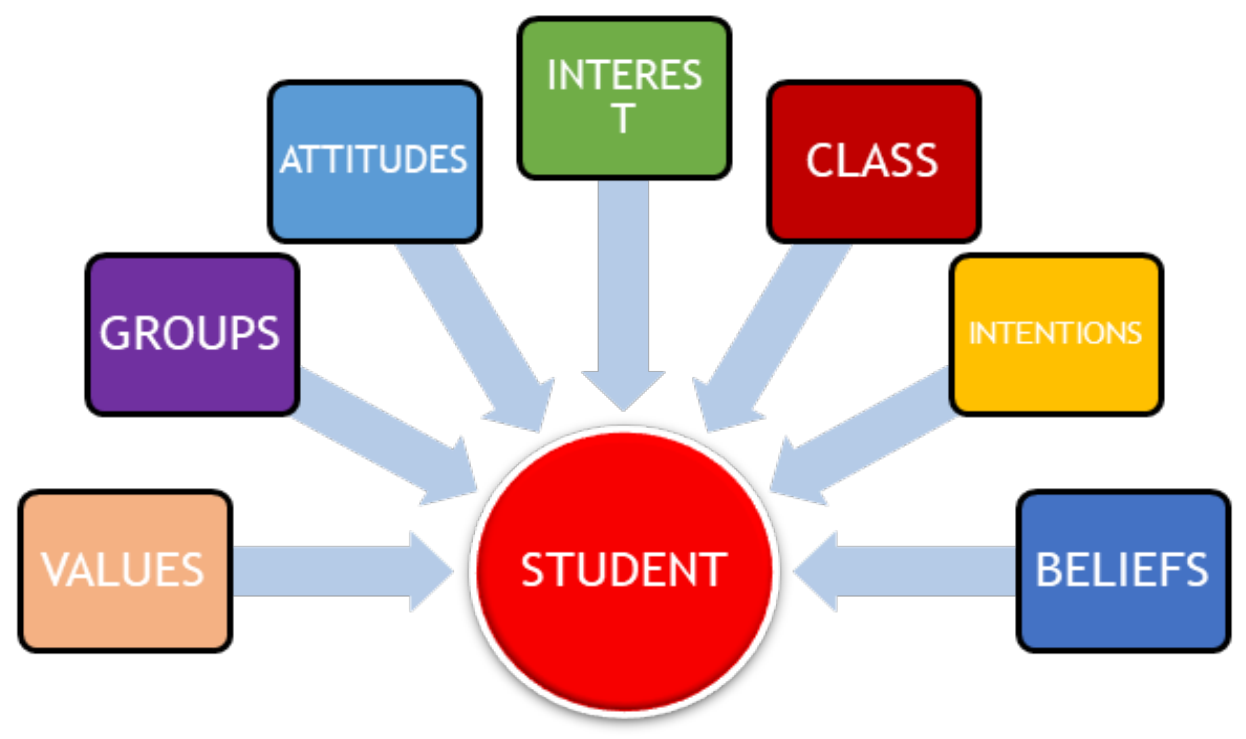

Fig. 1: The Student at the Center of Learning Source: SALAKO E. T.

\section{Cooperative Learning and Students' Knowledge of Multicultural Concepts}

Co-operative learning is a successful teaching strategy in which small teams (each with students of different levels of ability) use a variety of learning activities to improve their understanding of a subject. Kagan (2001) states that the main purpose of cooperative learning is to actively involve students in the learning process and improve inter-personal relationships among them. This would result into transformation in the society. The co-operative learning strategy is an effective teaching strategy which is aimed at accommodating learners from diverse cultural backgrounds (Salako, Eze \& Adu, 2012). Therefore, it has become necessary to address the global problem of cultural diversity through effective use of appropriate instructional strategy for teaching in Social Studies classrooms which contain students from diverse ethnic backgrounds.

Examining whether the adoption of cooperative learning strategy is likely to have an influence on students' knowledge of multicultural concepts is germane for evaluation of the strategy as one which could promote positive inter group relations. Several studies in which educators explored the influence of cooperative learning and students' knowledge of multicultural concepts suggest that this relationship is a positive one (Carter, 2005; Salako, 
Eze \& Adu, 2012). In a similar vein, Parker (2003) is of the opinion that a greater integration of multicultural curricular content with the use of effective teaching strategies would generally lead to improved rather than worsened or unchanged relations between groups. Therefore, cooperative learning is adjudged a viable strategy for teaching multicultural concepts because it promotes group work and the ability to achieve mutual learning goals (Ajitoni \& Salako, 2013). Highly structured cooperative learning allows students to develop their own understanding of key concepts all the while encouraging and assisting others (Samuel \& John, 2004).

\section{Hypotheses}

The following null and alternative hypotheses were formulated and tested at 0.05 level of significance;

HO1: There is no significant main effect of ethnic background on students' knowledge of multicultural education concepts

H1: There is a significant main effect of ethnic background on student's knowledge of multicultural education concepts

$\mathrm{HO} 2$ : There is no significant main effect of ethnic background on students' attitude to multicultural education concepts.

$\mathrm{H} 2$ : There is a significant main effect of ethnic background on students' attitude to multicultural education concepts

\section{Participants Characteristics}

The population sample for this study is 151 Junior Secondary School students randomly selected using the simple random technique from five secondary schools in the South-West region of Nigeria. They differ in terms of ethnic, language, beliefs, culture and many other variables. The state capital was purposively selected because of its multicultural nature in terms of getting students from various ethnic and religious backgrounds. Five secondary schools were purposively assigned to the experimental and control groups for the purpose of this study. The JS III students in these schools were considered appropriate for this study because concepts that were treated are found in the junior secondary school curriculum and the students are mature enough to reflect on their experiences. In all, one hundred and fifty one students participated in the study. Some of the participant characteristics are presented in Table 1 below: 
Table 1: Gender, age and class distribution of the students

\begin{tabular}{|c|c|c|}
\hline Variable & $\mathbf{F}$ & $\%$ \\
\hline \multicolumn{3}{|l|}{ STUDENTS' GENDER } \\
\hline Male & 81 & 53.3 \\
\hline Female & 70 & 46.7 \\
\hline Total & 151 & 100.00 \\
\hline \multicolumn{3}{|l|}{ STUDENTS'AGE } \\
\hline Less than $15 y r s$ & 89 & 56.7 \\
\hline $15-18 y r s$ & 62 & 39.3 \\
\hline Total & 151 & 100.00 \\
\hline \multicolumn{3}{|l|}{ STUDENTS' CLASS } \\
\hline JSS3 & 151 & 100.00 \\
\hline
\end{tabular}

\section{Sampling Procedure}

Using the simple random sampling technique, a sample of (151) students were selected for the study.

The schedule of the activities during the period is shown in Table 2 below : 
Table 2: Field Work Activities

\begin{tabular}{|c|c|c|c|}
\hline $\mathbf{S} / \mathbf{N}$ & WEEK & RESEARCH ACTIVITIES & TOPIC \\
\hline 1. & $\begin{array}{l}1 \text { st } \\
\text { Week }\end{array}$ & $\begin{array}{l}\text { Selection and training of } \\
\text { research assistants } \\
\text { Selection of schools }\end{array}$ & $\begin{array}{l}\text { The use of } \\
\text { research assistant } \\
\text { selection scale }\end{array}$ \\
\hline 2. & $\begin{array}{l}2^{\text {nd }} \\
\text { Week }\end{array}$ & $\begin{array}{l}\text { Categorization of schools into } \\
\text { experimental and control groups } \\
\text { Random selection of schools } \\
\text { Selection and training of } \\
\text { teachers }\end{array}$ & - \\
\hline 3. & $\begin{array}{c}3 \text { rd } \\
\text { Week }\end{array}$ & $\begin{array}{l}\text { Pre-test administration for } \\
\text { experimental and control groups }\end{array}$ & $\begin{array}{l}\text { Test items in the } \\
\text { questionnaire }\end{array}$ \\
\hline 4. & $\begin{array}{l}4^{\text {th }-9^{\text {th }}} \\
\text { Week }\end{array}$ & $\begin{array}{l}\text { Treatment administration and } \\
\text { follow-up }\end{array}$ & $\begin{array}{l}\text { Unity, culture, } \\
\text { peace, ethnic } \\
\text { groups, religion }\end{array}$ \\
\hline 5. & $\begin{array}{l}10^{\text {th }} \\
\text { Week }\end{array}$ & $\begin{array}{l}\text { Posttests administration for } \\
\text { experimental and control groups }\end{array}$ & $\begin{array}{l}\text { Test items in the } \\
\text { questionnaire }\end{array}$ \\
\hline
\end{tabular}

\section{Method}

\section{Research Design}

This study adopted the pretest - posttest, control group, quasi-experimental design.

In this design two groups of subjects are involved, the control and experimental. The subjects are assigned to two groups of randomization, both groups are given a pretest on the dependent variable and they were both given a posttest. Thereafter, the significance in the average score was determined as stated in tables 4 and 5 . 
The design is represented schematically as follows:

$\begin{array}{cccl}0_{1} & \mathrm{X}_{1} & 0_{3} & \text { Experimental group } \\ 0_{2} & \mathrm{X}_{2} & 0_{4} & \text { Control group }\end{array}$

Where $0_{1}$, and $0_{2}$, are pretest observations of experimental and control groups respectively.

$0_{3}$ and $0_{4}$ are the posttest observations of experimental and control groups respectively.

$\mathrm{X}_{1}=$ Cooperative learning. (Experimental group)

$\mathrm{X}_{2}=$ Conventional lecture Methods (control).

The design adopted a $2 \times 2 \times 2$ factorial matrix

The factorial matrix is presented in table 3 below:

$2 \times 2 \times 2$ Factorial Matrix

2 represents the treatments

2 represents Christianity and Islam (major religions in Nigeria)

2 represents the Yoruba and non-indigenes (non Yorubas)

Table 3: Table by Treatment, Religion and Ethnicity

\begin{tabular}{|c|c|c|c|}
\hline \multirow[b]{2}{*}{ Treatment } & \multirow[b]{2}{*}{ Religion } & \multicolumn{2}{|l|}{ Ethnicity } \\
\hline & & $\begin{array}{c}\text { Indigene } \\
\text { (Yoruba's) }\end{array}$ & $\begin{array}{l}\text { Non-Indigene } \\
\text { (non Yoruba's) }\end{array}$ \\
\hline \multirow{2}{*}{$\begin{array}{l}\text { Cooperative } \\
\text { Learning } \\
\text { Group }\end{array}$} & Christianity & 30 & 15 \\
\hline & Islam & 25 & 10 \\
\hline \multirow{2}{*}{$\begin{array}{l}\text { Control } \\
\text { Group }\end{array}$} & Christianity & 26 & 15 \\
\hline & Islam & 20 & 10 \\
\hline \multirow{2}{*}{$\begin{array}{l}\text { No of } \\
\text { students }\end{array}$} & Christianity & 56 & 30 \\
\hline & Islam & 45 & 20 \\
\hline
\end{tabular}




\section{Instrumentation}

The study employed Social Studies achievement and attitude test as its instrument:

Social Studies Achievement and Attitude Test (SAT)

The test item consists of thirty items which cut across Social Studies education related issues. The test items were drawn from the universal basic education curriculum on Social Studies education for junior secondary schools designed by Federal ministry of education, science and technology. The KR-20 formula yielded 0.82 reliability coefficient and an average item difficulty of 0.43 .

\section{Data Analysis}

Data collected were analyzed using descriptive statistics of frequency counts, means, percentages and standard deviation. Analysis of covariance (ANCOVA) statistics was used to test the hypotheses at 0.05 alpha level. The Multiple Classification Analysis (MCA) aspect of ANCOVA was used to determine the magnitude of the performance of the various groups.

\section{Findings}

Table 4: ANCOVA Summary of Posttest Knowledge of Multicultural Concepts by Treatment and Ethnicity

\begin{tabular}{|l|l|l|l|l|l|}
\hline \multirow{2}{*}{ Source of Variance } & \multicolumn{4}{l|}{ Hierarchical method } \\
\cline { 2 - 6 } & $\begin{array}{l}\text { Sum of } \\
\text { Squares }\end{array}$ & df & Mean square & F & Sig. \\
\hline $\begin{array}{l}\text { Covariates } \\
\text { SCORES }\end{array}$ & 1307.933 & 1 & 1307.933 & 112.318 & .000 \\
\hline $\begin{array}{l}\text { Main Effects } \\
\text { Combined }\end{array}$ & 1613.222 & 4 & 403.306 & 34.634 & .000 \\
\hline \multicolumn{1}{|c|}{ Treatment } & 135.892 & 2 & 67.946 & 5.835 & $.003^{*}$ \\
\hline Grpnic & 1477.297 & 1 & 1477.297 & 126.862 & $.000^{*}$ \\
\hline Model & 3325.191 & 11 & 302.290 & 25.959 & .000 \\
\hline Residual & 3959.283 & 340 & 11.645 & & \\
\hline Total & 7284.474 & 351 & 20.753 & & \\
\hline
\end{tabular}

* Significant at $\mathrm{p}<.05$ 
Table 4 shows a significant effect of treatment on students' posttest knowledge scores in multicultural concepts $\left(\mathrm{F}_{(2,340)}=5.835 ; \mathrm{p}<.05\right)$. This means that there is significant difference in the adjusted posttest scores of students exposed to the cooperative learning and conventional instructional strategies. Hence, null hypothesis 1 is rejected and alternative hypothesis 1 is not rejected

\section{Table 5: MCA of Posttest Knowledge Scores by Treatment and Ethnicity}

\begin{tabular}{|c|c|c|c|c|c|c|c|}
\hline \multirow[b]{2}{*}{$\begin{array}{l}\text { Variable + } \\
\text { category }\end{array}$} & \multirow[b]{2}{*}{$\mathrm{N}$} & \multicolumn{2}{|c|}{ Predicted Mean } & \multicolumn{2}{|c|}{ Deviation } & \multirow[b]{2}{*}{ Eta } & \multirow[b]{2}{*}{ Beta } \\
\hline & & Unadjusted & $\begin{array}{l}\text { Adjust- } \\
\text { ed for } \\
\text { factors } \\
\text { and co- } \\
\text { variates }\end{array}$ & $\begin{array}{l}\text { Unad- } \\
\text { justed }\end{array}$ & $\begin{array}{l}\text { Adjusted for } \\
\text { factors and } \\
\text { covariates }\end{array}$ & & \\
\hline $\begin{array}{l}\text { Treat - } \\
\text { ment } \\
\text { Coop }\end{array}$ & 101 & 10.79 & 10.14 & 1.4 & .83 & \multirow[b]{2}{*}{25} & \multirow[b]{2}{*}{24} \\
\hline Control & 126 & 7.95 & 7.85 & -1.35 & -1.45 & & \\
\hline $\begin{array}{l}\text { Ethnic } \\
\text { Grp } \\
\text { Indigene }\end{array}$ & & & & & & \multirow[b]{2}{*}{.39} & \multirow[b]{2}{*}{.46} \\
\hline $\begin{array}{l}\text { Indigene } \\
\text { Non-in- } \\
\text { digene }\end{array}$ & $\begin{array}{l}210 \\
41\end{array}$ & $\begin{array}{l}9.96 \\
4.48\end{array}$ & $\begin{array}{l}10.08 \\
3.59\end{array}$ & $\begin{array}{l}.65 \\
-4.83\end{array}$ & $\begin{array}{l}.77 \\
-5.71\end{array}$ & & \\
\hline $\mathrm{R}=$ & .63 & & & & & & \\
\hline R Squared & $=.40$ & & & & & & \\
\hline
\end{tabular}

The MCA (table 5) reveals that the cooperative learning group had higher adjusted posttest knowledge score $(=10.14$; Dev. $=.83)$ than those in the control group ( $=7.85$; Dev. $=-1.45)$.

This implies that the cooperative learning instruction proved effective followed by the conventional teaching method. 
Salako, E. T. \& Ojebiyi, O. A./ Teaching Social Studies from Multilcultural Perspective

Table 6: ANCOVA Summary of Posttest Attitude Scores by Treatment and Ethnicity

\begin{tabular}{|l|l|l|l|l|l|}
\hline \multirow{2}{*}{ Source of Variance } & \multicolumn{4}{|l|}{ Hierarchical method } & \multicolumn{2}{l|}{} \\
\cline { 2 - 6 } & $\begin{array}{l}\text { Sum of } \\
\text { Squares }\end{array}$ & df & Mean square & F & Sig. \\
\hline Covariates PREATTD & 61.435 & 1 & 61.435 & .194 & .660 \\
\hline Main Effects Combined & 21824.697 & 4 & 5456.174 & 17.200 & .000 \\
\hline Treatment & 21605.475 & 2 & 10802.738 & 34.055 & $.000 *$ \\
\hline Ethnic Grp & 21.652 & 1 & 21.652 & .068 & .794 \\
\hline Model & 27786.461 & 11 & 2526.042 & 7.963 & .000 \\
\hline Residual & 107853.51 & 340 & 317.216 & & \\
\hline Total & 135639.97 & 351 & 386.439 & & \\
\hline
\end{tabular}

* Significant at $\mathrm{p}<.05$

Table 6 shows that there is significant effect of treatment on students' attitude to multicultural concepts

$\left(\mathrm{F}_{(2,340)}=34.055 ; \mathrm{P}<.05\right)$. Hence, null hypothesis 2 is rejected and the alternative hypothesis 2 is not reject-ed 
Table 7: MCA of Posttest Attitude Scores by Treatment and Ethnicity

\begin{tabular}{|c|c|c|c|c|c|c|c|}
\hline \multirow[b]{2}{*}{$\begin{array}{l}\text { Variable + } \\
\text { category }\end{array}$} & \multirow[b]{2}{*}{$\mathrm{N}$} & \multicolumn{2}{|c|}{ Predicted Mean } & \multicolumn{2}{|c|}{ Deviation } & \multirow[b]{2}{*}{ Eta } & \multirow[b]{2}{*}{ Beta } \\
\hline & & $\begin{array}{l}\text { Unad- } \\
\text { justed }\end{array}$ & $\begin{array}{l}\text { Adjusted } \\
\text { for factors } \\
\text { and co- } \\
\text { variates }\end{array}$ & $\begin{array}{l}\text { Unad- } \\
\text { justed }\end{array}$ & $\begin{array}{l}\text { Adjusted } \\
\text { for fac- } \\
\text { tors and } \\
\text { covari- } \\
\text { ates }\end{array}$ & & \\
\hline $\begin{array}{l}\text { Treatment } \\
\text { Coop }\end{array}$ & 125 & 82.26 & 79.05 & 4.144 & 3.99 & & \\
\hline Control & 126 & 64.67 & 64.71 & -10.38 & -10.35 & .399 & .399 \\
\hline $\begin{array}{l}\text { Ethnic } \\
\text { Group } \\
\text { Indigene } \\
\text { Non-indi- } \\
\text { gene }\end{array}$ & 210 & $\begin{array}{l}74.54 \\
78.86\end{array}$ & $\begin{array}{r}75.24 \\
73.69\end{array}$ & $\begin{array}{l}-.52 \\
3.80\end{array}$ & $\begin{array}{l}.19 \\
-1.37\end{array}$ & .071 & .026 \\
\hline $\begin{array}{l}\mathrm{R}= \\
\mathrm{R} \text { Squared }=\end{array}$ & $\begin{array}{l}.40 \\
16\end{array}$ & & & & & & \\
\hline
\end{tabular}

From Table 7, the cooperative learning group had higher adjusted posttest attitude score

$(=82.26$; Dev. $=7.20)$ than the control group $(=64.67$; Dev. $=3.99)$.

\section{Discussion}

It was found in this study that the effect of treatment on students' knowledge of, and attitude to, multicultural concepts is significant. This is to the effect that the cooperative learning strategy was more effective than the conventional teaching method. The superiority of the cooperative learning mode of instruction over the other strategy is founded upon the nature of interaction among the students in the learning situation. For instance, within each group, students from diverse cultural, ethnic and religious backgrounds were provided equal opportunities and interacted to achieve common goals. Also, students of different levels of abilities used the variety of learning activities provided to improve on their understanding of the multicultural concepts within inter group and intra group setting. Indeed, the cooperative learning instruction fostered greater student attention and stimulated interest through the exploration of the different cultures presented to them. 
Another possible reason for the effectiveness of cooperative learning is that students' various interests, needs and challenges were accommodated and taken care of through multicultural concepts presented to the cultural heterogeneous group. They are also encouraged to make critical decisions concerning themselves, as well as concerning others in the group. Cooperative learning is indeed experiential in the context and helped to reinforce students' learning while experiencing realistic situations, applying practical knowledge and connecting with the community. Cooperative learning is the instructional use of small groups so that students could work together to maximize their own and each other's learning. Therefore, co-operative learning is an effective teaching strategy which is aimed at accommodating learners from diverse cultural backgrounds. This finding is in agreement with those of Slavin (2001), Williams (2007), Fink (2004) and Lie (2008) that cooperative learning is not only viable in classrooms but the strategy helps students to become effective leaders, communicators and listeners. Students are future leaders, hence the need to catch them young by equipping them with knowledge to help them make sound decisions rather than change the negative attitudes already formed by adults.

Two African insurgencies now rank among the most dangerous internationally: Boko Haram in Nigeria and Somalia's al-Shabab, with violence spilling into neigbouring countires such as Chad, Cameroun and Niger. Al-Shabab terrorist attack against Watergate Mall and other attacks in Nairobi, Kenya have claimed hundreds of lives and hammered the tourism industry. Similarly, terrorist incidences have increased across Libya, even resulting in the evacuation of staff of the United States of America embassy in Tripoli. South Africa, Rwanda, Liberia, Egypt, Mali, Algeria, Ethiopia, Sudan, Tanzania, Eritrea, Democratic Republic of Congo, Uganda all have an unenviable record of insurgencies. The background of some of these insurgent groups' participants suggests strongly that education remains the core of national stability in a world where people continually encounter problems such as racism, sexism, prejudice and discrimination in the society.

It is worthy to commend the great efforts of the University of Ghana for celebrating Kwame Nkrumah who was one of Africa's great sons. The efforts of organisations such as Association for the Development of Education in Africa (ADEA), Education for all (EFA), United Nations Educational, Scientific and Cultural Organisation (UNESCO), Social Studies Association of Nigeria (SOSAN), World Bank Group, MDGs, NGOs forum for policy dialogue and catalyst for educational reforms are highly appreciated. Such efforts need to be complimented by other concerned groups and individuals because the role of education in national integration cannot be overemphasized. In any democratic society, education remains the core of national stability, security 
and an instrument for political and economic growth and development. Thus, if there is integration of effective teaching and learning strategies into the mainstream of educational systems in Africa, there would be global peace and unity.

\section{Conclusion}

Based on the findings of this work, it could be concluded that Multicultural Education should be implemented widely in all schools, colleges and universities. The large number of national conferences, school workshops and teacher education courses in multicultural education are evidence of its success and perceived importance. Although the process of integration of content is so often contentious, textbooks publishers are also integrating ethnic and cultural contents into their books and the pace of such integration is increasing (Banks, 2003).

Multicultural education is part of a greater plan to support togetherness through education, urging people of different origins and different bloods to acknowledge cultural identity as a means to transform society. Therefore, education is the foundation on which future generation will help guide society into another age of enlightenment. (Wiedeman, 2002). This paper has outlined cooperative multicultural strategy which would incorporate social equity into our communities, homes and especially our schools through multicultural education. The classroom is a very complex micro-culture, consisting of unique individuals and a variety of cultures. Each individual brings with $\mathrm{him} /$ her a distinct set of beliefs, values and experiences, which influences the attitudes, behaviours and perceptions of the classroom as a whole. All cultural values should be seen as important.

\section{Recommendations}

It is hereby recommended that:

1. Educators should adopt the cooperative learning strategy in the teaching of multicultural concepts in all subject areas in order to better prepare the students for future communal living, understanding of other peoples' culture and development of abilities to live peacefully with others especially outside of their own culture or ethnic origins.

2. Students should be assisted to appreciate the need for national unity, peace, love and harmony and the need to contribute to its entrenchment in the society. This could be achieved through the inclusion of more group work activities in classroom teaching. Through group work activities, students would learn to be more sociable and tolerant of others' ways of life.

3. Curriculum developers should popularize cooperative learning by recommending its use to teachers in the curriculum. 
Salako, E. T. \& Ojebiyi, O. A./ Teaching Social Studies from Multilcultural Perspective

4. Teachers' associations should organize conferences, seminars and workshop for teachers in order to make them familiar and interested in the use of the cooperative learning and multicultural concepts specifically. 


\section{References}

Ajitoni, S.O., \& Salako, E.T. (2013). Effects of cooperative learning and field trip strategies on secondary school students' knowledge of and attitudes to multicultural concepts in Social Studies. Journal of education and practice. Vol.4 (22), pp 35-42. www.iiste.org Audrey R (1995).The Multicultural States of East Africa.Montreat: McGillQueen's University Press.

Banks, J.A. (2003).Diversity and citizenship Education: Global perspectives. San Francisco: Jossy- Bass

Banks, J.A (2008). An Introduction to multicultural Education. Boston: Allyn and Bacon.

Carter, P. L. (2005). Keeping' it real: School success beyond black and white New York: Oxford University Press.

Davidman, L., \& Davidman, P. (1997). Teaching with a Multicultural perspective: A practical guide. New York: Longman.

Emmaji, M. (2014). Multiculturalism and Democracy in North Africa: Aftermath of the Arab spring. Routledge.

Fink, L.D. (2004). Beyond small groups: Harnessing the extraordinary power of learning. In Michaelsen L., Knight, A. \& Fink L.D. TeamBased Learning: A transformative use of small groups. Sterling, VA: Stylus Publishing.

Kagan, S., (2001). Kagan structures: Research and rationale. Retrieved from http://www.kaganonline.com/free_articles/dr_spencer_kagan/ research_in_nutshell.p.

Lie, A. (2008). Cooperative learning: Changing paradigms of college teaching. Retrieved July 16, 2008 from http://faculty.petra.ac.id /anitalie/LTM/ cooperative_learning.html

Parker, W.C. (2003). Teaching democracy: Unity and diversity in public life. New York: Teachers College Press

Prb-Wpds (2016). www.worldpopdata.org

Salako, E.T., Eze, I.R. \& Adu, E.O. (2012). Effects of cooperative learning on secondary school students' knowledge of and attitudes to multicultural concepts in Social Studies. Research educational discovery science journal.2 (4), 5-18

Samuel, W.W. \& John, G.M. (2004). Effects of cooperative class experiment teaching method on secondary school students' chemistry achievement in Kenya's Nakuru district. International education journal, 5 (1), 26-35. 
Salako, E. T. \& Ojebiyi, O. A./ Teaching Social Studies from Multilcultural Perspective

Venter, E., Franzsen. K. \& Van Heerden, E. (2000). An Analysis of the Effect of Recent National Policy Changes on Values and Education in South Africa. Systems of Education: Theories, Policies, and Implicit Values, 194. Pretoria: https/www.up.ac.za

Wiedman, C.R. (2002). Teacher Preparation, Social Justice, Equity: A review of the Literature. Electronic version. http://ejournals.ebsco. com.libezp.lib.isu.edu. 